\title{
Effect of Chromate Inhibitor on the Corrosion Rate of API 5L Grade B Steel Pipe in The Injection Water
}

\author{
P. T. Iswanto ${ }^{1}$, A. Shah ${ }^{1}$, H. M. Sadida ${ }^{1}$ \\ 'Departemen Teknik Mesin dan Industri Fakultas Teknik Universitas Gadjah Mada \\ Yogyakarta 55281, Indonesia \\ Telp. (0274) 521673 \\ *e-mail: priyotri@ugm.ac.id
}

\begin{abstract}
Abstrak
Corrosion inside the injection water pipe occurs from the Central Injection Facility Station to the wellhead. One way to reduce the rate of corrosion is to add inhibitors. This research is looking for the effect of variations in the concentration of the sodium chromate inbibitor $\left(\mathrm{Na}_{2} \mathrm{CrO}_{4}\right)$ on the corrosion rate of API $5 \mathrm{~L}$ grade B pipes used in the oil industry, especially in injection water fluids. For comparison, a corrosion rate test was carried out on a $3.5 \% \mathrm{NaCl}$ solution. The study used an NPS 4 SCH 40 pipe with an outer diameter of 4.5 in $(114.3 \mathrm{~mm})$ with a thickness of 0.237 in $(6.02 \mathrm{~mm})$. The concentration parameter of the Sodium Chromate inhibitor used is $0.1 ; 0.3 ; 0.5 ; 0.7$ and $0.9 \%$. The study used a corrosion rate test using the potentiodynamic polarization method. The results showed the pipe corrosion rate in the injection water fluid was 0.3307 mpy, and the pipe corrosion rate in the 3.5\% NaCl solution was 0.4960 mpy. The addition of chromate inhibitors succeeded in decreasing the corrosion rate. The maximum condition is achieved with the addition of $0.9 \%$ inhibitor. In this condition, the corrosion rate of the pipe in the injection water solution is 0.2175 mpy and the corrosion rate of the pipe in the $3.5 \% \mathrm{NaCl}$ solution is $0.3218 \mathrm{mpy}$.
\end{abstract}

Keywords: API 5L Grade B pipe, water injection, chromate inbibitor, corrosion rate.

\begin{abstract}
Abstrak
Korosi di bagian dalam pipa air injeksi terjadi mulai dari Stasiun Fasilitas Injeksi Pusat sampai ke sumur (wellhead). Salah satu cara untuk mengurangi laju korosi adalah dengan menambahkan inhibitor. Penelitian ini mencari pengaruh variasi konsentrasi inhibitor Natrium Kromat (Na2CrO4) terhadap laju korosi pipa API 5L grade B yang dipakai di industri minyak terutama pada fluida air injeksi. Sebagai perbandingan, dilakukan uji laju korosi pada larutan 3,5\% $\mathrm{NaCl}$. Penelitian menggunakan pipa NPS 4 sch 40 diameter luar 4,5 in (114,3 mm) dengan tebal 0,237in $(6,02 \mathrm{~mm})$. Parameter konsentrasi inhibitor Natrium Kromat yang digunakan adalah 0,1;0,3; 0,5; 0,7 dan $0,9 \%$. Penelitian menggunakan alat uji laju korosi dengan metode polarisasi potensiodinamik. Hasil penelitian menunjukkan laju korosi pipa di fluida air injeksi sebesar 0,3307 mpy dan laju korosi pipa di larutan 3,5\% $\mathrm{NaCl}$ sebesar 0,4960 mpy. Penambahan inhibitor kromat berhasil menurunkan laju korosi. Kondisi maksimal dicapai pada penambahan 0,9\% inhibitor. Pada kondisi ini, laju korosi pipa di larutan air injeksi adalah 0,2175 mpy dan laju korosi pipa di larutan 3,5\% $\mathrm{NaCl}$ adalah 0,3218 mpy.
\end{abstract}

Kata kunci: Pipa API 5L Grade B, air injeksi, inhibitor kromat, laju korosi. 


\section{INTRODUCTION}

In every process of production, there is residual material production. This also happened in the oil and gas industry. In the oil industry, besides producing crude oil, there are other substances that are produced, namely gas, sand and water. As an oil well grows, the amount of water will increase. The water is cleaned in a Gathering Station then injected into a rock formation in the ground.

API 5L grade B carbon steel pipe is often used as equipment for sending various kinds of fluids such as crude oil, produced water, injection water, waste brine, natural gas and other fluids. The relatively low price of carbon steel material is a major factor in the choice of material. Naturally, carbon steel pipe material will interact with the environment on the outside of the pipe and on the inside of the pipe so that various types of corrosion occur with different corrosion rates.

Corrosion control of carbon steel pipes is a topic that is often discussed in various forums of practitioners, researchers and academics. The most common practice is controlling corrosion with paint or coating on the outside of the pipe, adding sacrificial anodes to the pipe segments that have high corrosion rates and adding inhibitors to the fluid flowing in the pipe.

Inhibitors are organic and inorganic substances which when added in small amounts to a corrosive environment will inhibit or reduce the rate of corrosion. One way the inhibitor works is to form a thin layer on the surface of carbon steel material. The challenge in choosing an inhibitor is to determine the type and concentration of the right inhibitor for a particular corrosion condition.

According to Finsgar and Jackson (2013), the effectiveness of inhibitors increases with increasing concentrations of inhibitors, but the effectiveness decreases with increasing temperatures. The conclusion was obtained after conducting a review of the use of various types of inhibitors for steel material in acid media found in the oil and gas industry. Meresht et al. (2012) also state that the efficiency of the inhibitor increases with increasing concentration of the inhibitor but the efficiency decreases with increasing temperature.

According to Oliveira (2018), silicate-based film coatings can improve the corrosion resistance of API 5L X80 steel pipes on carbonate-bicarbonate media at room temperature. Diaz et al. (2017) explain that imidazoline inhibitors can form a film layer on the API 5L X70 pipe so that it reduces the flow assisted corrosion rate with sour brine media. The inhibitor film produces an efficiency of $70-99 \%$ at a concentration of $200 \mathrm{ppm}$. In conditions of higher flow rates, turbulence occurs to reduce the efficiency of the inhibitor because the film layer is formed imperfectly.

The purpose of this study was to determine the effect of chromate inhibitors on the corrosion rate of API 5L grade $\mathrm{B}$ pipe used in the injection water environment and $3.5 \% \mathrm{NaCl}$ solution. Chromate inhibitors used were Sodium Chromate $(\mathrm{Na} 2 \mathrm{CrO} 4)$ with variations in the concentration of the inhibitor was $0.1 ; 0.3 ; 0.5 ; 0.7$ and $0.9 \%$. 


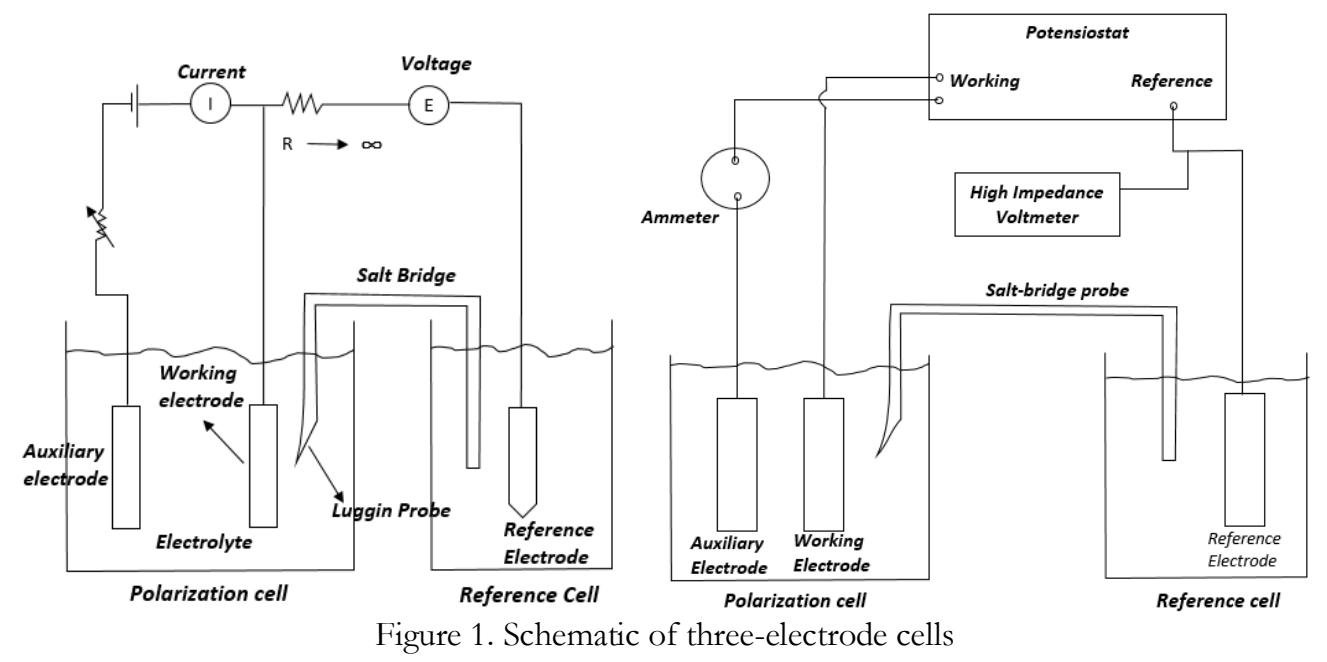

\section{METHODOLOGY}

The study was conducted at the Laboratory of Engineering Materials, Department of Mechanical and Industrial Engineering in the span of July - October 2018. The series of tests carried out are as follows:
a. Material composition test
b. Microstructure test
c. Hardness Test
d. Tensile test
e. Corrosion rate test

Material composition test, microstructure test, hardness test and tensile test are used for validation of API 5L Grade B pipe material specimens. Material composition tests are also useful in calculating the equivalent weight used for calculating corrosion rates.

Corrosion rate testing uses a Versa STAT4 three-cell electrode tool with a potentiodynamic polarization method to find the relationship of corrosion current $\left(\mathrm{i}_{\text {corr }}\right)$. with corrosion stress $\left(\mathrm{E}_{\mathrm{corr}}\right)$. The three-electrode cells as described in Figure 1 are standard laboratory devices for quantitative research on the corrosion properties of materials (ASM Corrosion Handbook Volume 13.1992). The three cell electrode components are as follows:

a. Working electrode. This is the designation given to the electrodes studied. Corrosion rate test specimens prepared from API 5L grade B pipes will be installed at this working electrode.

b. Auxiliary electrodes. This designation is given to the second electrode which is explicitly intended to transport current in the circuit formed in the study.

c. Reference electrode (reference electrode). This electrode is intended as an excellent base point for reference to the measurement of the working electrode potential. In this study, we use a saturated $\mathrm{KCl}$ solution. Some other test equipment uses a Saturated Calomel Electrode (SCE) as a reference electrode

The 3rd cell electrode scheme and the instrumentation used in the potentiodynamic polarization experiment are explained in Figure 1. The corrosion rate test is carried out 12 times with different media and chromate concentrations as described in Table 1. Figure 2 explains the ideal relationship between corrosion currents $\left(\mathrm{i}_{\text {corr }}\right)$. with a potential difference $\left(\mathrm{E}_{\text {corr }}\right)$. 
between the working electrode and the reference electrode (ASM Corrosion Handbook Volume 13, 1992).

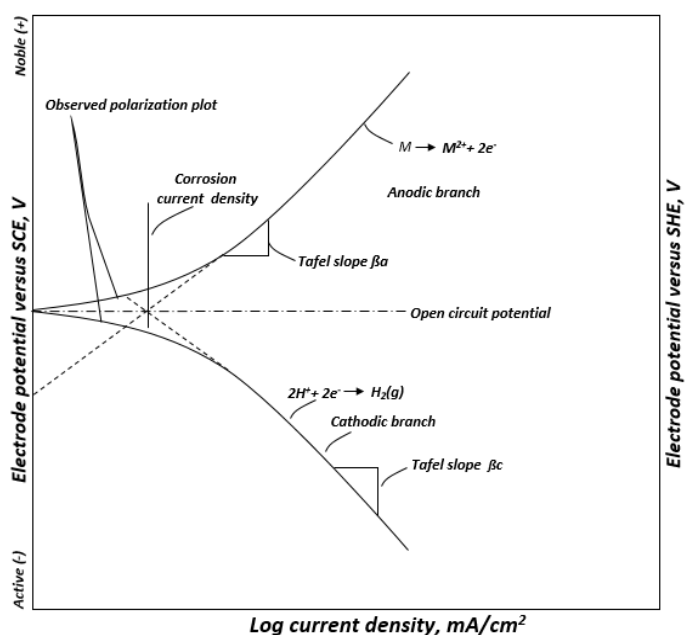

Figure 2. The Icorr and Ecorr ideal results in the potentiodynamic polarization test

Table 1. Corrosion rate test media

\begin{tabular}{ccc}
\hline No. & Media & Chromate (\%) \\
\hline 1 & Injection Water & 0 \\
2 & Injection Water & 0,1 \\
3 & Injection Water & 0,3 \\
4 & Injection Water & 0,5 \\
5 & Injection Water & 0,7 \\
6 & Injection Water & 0,9 \\
7 & $3,5 \% \mathrm{NaCl}$ solution & 0 \\
8 & $3,5 \% \mathrm{NaCl}$ solution & 0,1 \\
9 & $3,5 \% \mathrm{NaCl}$ solution & 0,3 \\
10 & $3,5 \% \mathrm{NaCl}$ solution & 0,5 \\
11 & $3,5 \% \mathrm{NaCl}$ solution & 0,7 \\
12 & $3,5 \% \mathrm{NaCl}$ solution & 0,9 \\
\hline
\end{tabular}

Based on the ASTM G102 standard, this research use Faraday's law to calculate the corrosion rate in the form of Penetration Rate (CR) in units of ( $\mathrm{mm} /$ year), as expressed in Eq (1)

$$
C R=K_{1}\left(\frac{i_{c o r r}}{\rho}\right) E W
$$

where

$\mathrm{CR}$ is Corrosion Rate in $\mathrm{mm}$ /year,

$i_{\text {corr }}$ is the density of the corrosion current $\left(\mu \mathrm{A} / \mathrm{cm}^{2}\right)$ 


$$
\mathrm{K}_{1}=3,27 \times 10^{-3},(\mathrm{~mm} \mathrm{~g} / \mu \mathrm{A} \mathrm{cm} \text { year })
$$

$Q$ is density of the matrial $\mathrm{g} / \mathrm{cm}^{3}$

$\mathrm{EW}$ is equivalent weight or equivalent weight, which we interpret as the amount of mass of metal in grams which will be oxidized when getting an electric charge of one Faraday (96 $489 \pm 2 \mathrm{C}$ (amp-sec)). EW can be expressed in Eq (2)

$$
E W=\frac{1}{Q}
$$

Seda while the $\mathrm{Q}$ value for a material consisting of several elements is calculated according to the formula such as shown in Eq (3)

$$
Q=\sum \frac{n_{i} f_{i}}{W_{i}}
$$

where

$\mathrm{n}$ is the number of valence electrons of the constituent elements of the metal alloy

$\mathrm{f}$ is the mass fraction of the constituent elements of the metal alloy

$\mathrm{W}$ is the atomic weight of the alloying elements

The metal constituents used to calculate $\mathrm{Q}$ are elements with a mass fraction greater than $1 \%$. In accordance with the test results of the material composition of API $5 \mathrm{~L}$ grade $\mathrm{B}$ pipe specimens, then we only use the element Fe in the calculation of Q.

\section{RESULT AND DISCUSSION}

The composition test results using Spectrometer analysis with the FELAST program are described in Table 2. The main composition of API 5L Grade B material is Fe with a percentage of alloy elements of $98.99 \%$ followed by Mn alloy elements of $0.6371 \%$, elemental alloy C of $0.14 \%$ and Si alloy elements at $0.1342 \%$.

Table 2. Material Composition

\begin{tabular}{ccc}
\hline Elements & Sample & Standard API \\
\hline $\mathbf{C}$ & 0,1417 & $0,26 \max$ \\
$\mathbf{S i}$ & 0,1342 & \\
$\mathbf{S}$ & 0,0290 & $0,030 \max$ \\
$\mathbf{P}$ & 0,0061 & $0,030 \max$ \\
$\mathbf{M n}$ & 0,6371 & $1,2 \max$ \\
$\mathbf{N i}$ & 0,0104 & $0,5 \max$ \\
$\mathbf{C r}$ & 0,0144 & $0,5 \max$ \\
$\mathbf{M o}$ & 0,0013 & $0,15 \max$ \\
$\mathbf{C u}$ & 0,0091 & $0,5 \operatorname{maks}$ \\
$\mathbf{T i}$ & 0,0009 & $\mathrm{Nb}+\mathrm{V}+\mathrm{Ti} \leq 0,15$ \\
$\mathbf{N b}$ & 0,0007 & $\mathrm{~V}+\mathrm{Nb} \leq 0,06$
\end{tabular}


P. T. Iswanto et al. / Journal of Mechanical Design and Testing 1(2), (2019), 116-125

V $\quad 0,0035 \quad \mathrm{~V}+\mathrm{Nb} \leq 0,06$

Fe $\quad 98,99$

Observation of the microstructure of API 5L Grade B material using an optical microscope. The specimen preparation follows a standard metallographic procedure which includes the sanding, polishing and etching processes. The results of microstructure observations made on API grade 5L API B are shown in Figure 3. The microstructure of API $5 \mathrm{~L}$ grade $\mathrm{B}$ consists of light-colored ferrite/white and dark-colored pearlite.

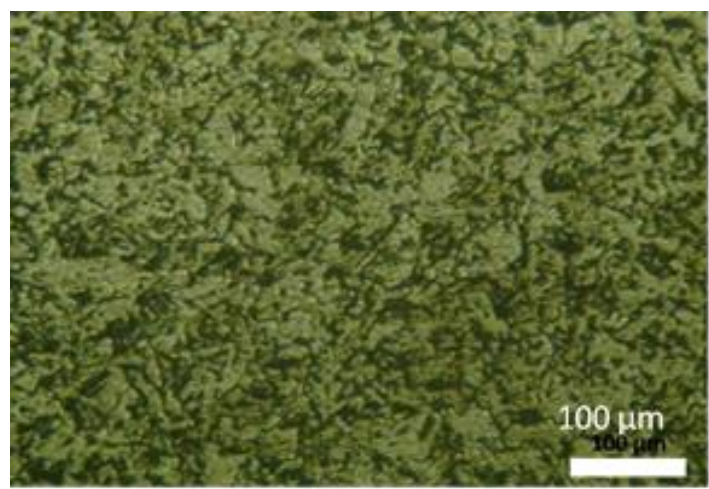

Figure 3. Micro structure of API 5L Grade B

Hardness testing was carried out on the surface of API 5L grade B material with the Buehler microhardness tester using the Vickers method. The results of the surface hardness test are shown in Table 3.

Table 3. Vickers Hardness Test

\begin{tabular}{ccc}
\hline $\mathrm{P}($ gr.f $)$ & $\mathrm{d}^{2}\left(\mathrm{~mm}^{2}\right)$ & $\mathrm{VHN}\left(\mathrm{kg} / \mathrm{mm}^{2}\right)$ \\
\hline 200 & 2,339 & 158,571 \\
\hline
\end{tabular}

Tensile test specimens in this study refer to ASTM E8 and use the Servopulser brand tensile testing machine with a maximum load of 10 tons. The tensile test is carried out to determine the mechanical properties of the material. From the test obtained graph yield stress (yield stress) and maximum tensile stress (ultimate tensile stress) as shown in Table 4.

Table 4. Tensile Test

\begin{tabular}{ccc}
\hline Specimen & $\sigma_{\mathrm{y}}(\mathrm{Mpa})$ & $\sigma_{\mathrm{u}}(\mathrm{Mpa})$ \\
\hline 1 & 466,42 & 518,24 \\
2 & 456,05 & 511,77 \\
3 & 450,87 & 519,54 \\
\hline Average & 457,78 & 516,52 \\
\hline Standard API & 245 & 415 \\
\hline
\end{tabular}


Based on material composition test data, microstructure test, hardness test, and tensile test show that the pipe specimens used in this study have met API $5 \mathrm{~L}$ grade $\mathrm{B}$. The corrosion rate test results with potentiodynamic methods are shown in Table 5 below.

Table 5. Corrosion Rate Result

\begin{tabular}{cccc}
\hline No & Media & Chromate $(\%)$ & Corrosion Rate (mpy) \\
\hline 1 & Injection Water & 0 & 0,3307 \\
2 & Injection Water & 0,1 & 0,3030 \\
3 & Injection Water & 0,3 & 0,2848 \\
4 & Injection Water & 0,5 & 0,2679 \\
5 & Injection Water & 0,7 & 0,2567 \\
6 & Injection Water & 0,9 & 0,2175 \\
7 & $3,5 \% \mathrm{NaCl}$ solution & 0 & 0,4960 \\
8 & $3,5 \% \mathrm{NaCl}$ solution & 0,1 & 0,4187 \\
9 & $3,5 \% \mathrm{NaCl}$ solution & 0,3 & 0,3849 \\
10 & $3,5 \% \mathrm{NaCl}$ solution & 0,5 & 0,3741 \\
11 & $3,5 \% \mathrm{NaCl}$ solution & 0,7 & 0,3739 \\
12 & $3,5 \% \mathrm{NaCl}$ solution & 0,9 & 0,3218 \\
\hline
\end{tabular}

The corrosion rate of API 5L grade B pipe in the injection water medium is 0.3307 mpy and the corrosion rate in the $3.5 \%$ solution is $0.4960 \mathrm{mpy}$. The addition of chromate inhibitors decreased the corrosion rate of API $5 \mathrm{~L}$ grade $\mathrm{B}$ pipe in the injection water medium and $3.5 \% \mathrm{NaCl}$ solution. The higher the chromate concentration, the lower the corrosion rate as shown in Figure 4. This is consistent with research conducted by Finsgar and Jackson (2013) as well as research conducted by Meresht et al (2012). The lowest corrosion rate was achieved at $0.9 \%$ chromate concentration, ie the corrosion rate in the injection water medium was 0.2175 mpy and in a solution of $3.5 \% \mathrm{NaCl}$ reached 0.3218 mpy.

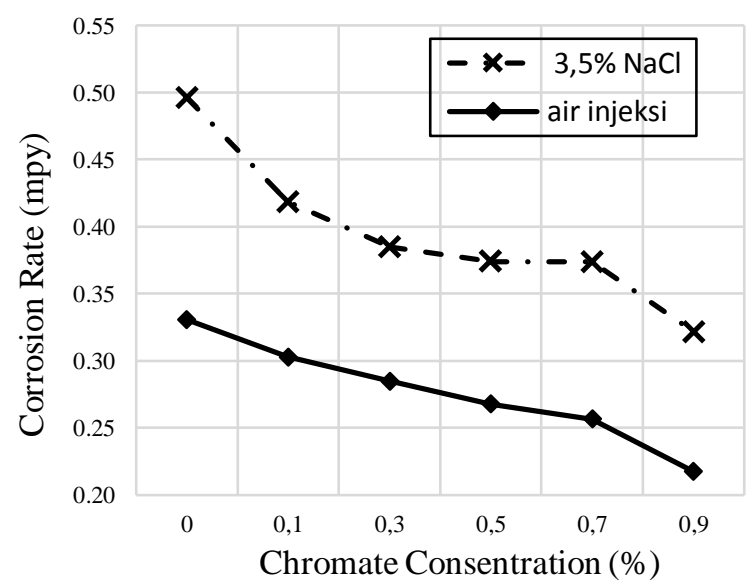

Figure 4. Effect of chromate inhibitor on the corrosion rate of API 5L Grade B 
The addition of chromate inhibitors to the injection water medium influences the shape of the potentiodynamic test results graph as shown in Figure 5. The graph changes very slowly and shifts to the left so that the corrosion current becomes lower. At a concentration of $0.9 \%$ chromate, the graph is seen in the far-left position and shifted upward so that it shows changes in material properties to be more noble or "noble" against corrosion.

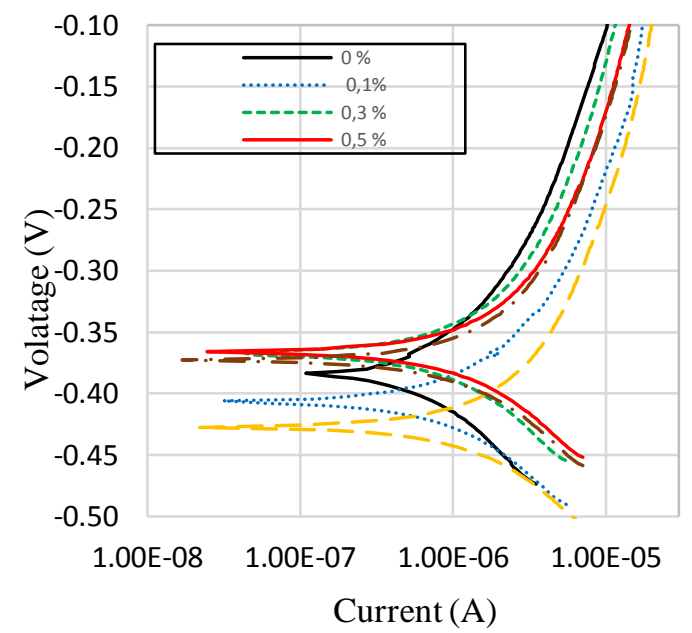

Figure 5. Potentiodynamic test results on injection water media with various chromate concentrations.

Figure 6 shows the potentiodynamic results in a solution of $3.5 \% \mathrm{NaCl}$. The addition of chromate changes the graph to be gentler but not too extreme as in water injection media. At a concentration of $0.9 \%$ chromate, the graph is seen in the far-left position and shifted upward so that it shows changes in material properties to be more noble or "noble" against corrosion.

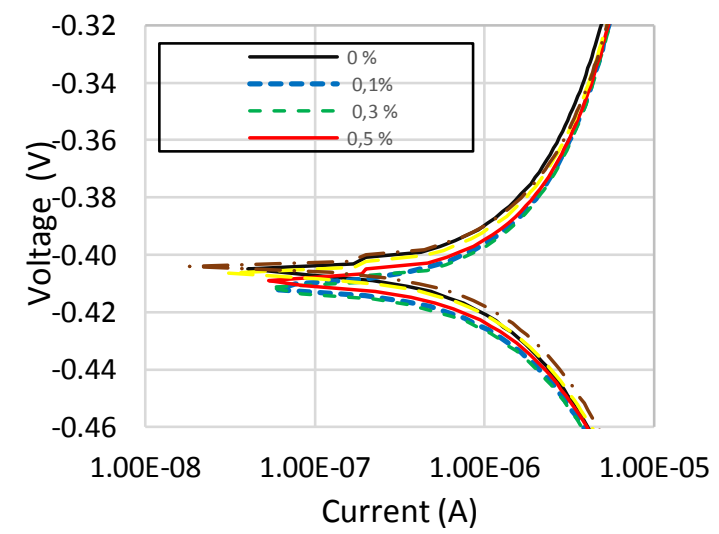

Figure 6. Potentiodynamic test results on a solution of $3.5 \% \mathrm{NaCl}$ with various chromate concentrations 
The effectiveness of the inhibitor is calculated based on the magnitude of the decrease in the rate of corrosion compared to the rate of corrosion without the inhibitor, such as expressed in Eq (4). According to the data in Table 6 and Figure 7, the effectiveness of the inhibitor increases with increasing concentration of the inhibitor. The maximum condition is achieved when the inhibitor concentration is $0.9 \%, 34.23 \%$ for injection water media and $35.13 \%$ for a solution of $3.5 \% \mathrm{NaCl}$.

$$
\text { Eff inhibitor }=\frac{C R_{1}-C R_{0}}{C R_{0}} \times 100 \%
$$

where

$\mathrm{CR}_{1}=$ corrosion rate after adding inhibitors

$\mathrm{CR}_{0}=$ corrosion rate without inhibitors

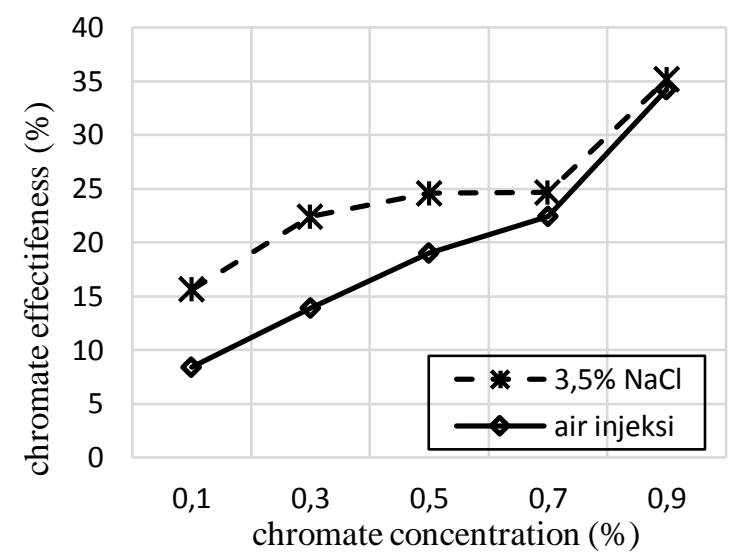

Figure 7. Effect of chromate inhibitor concentration on the effectiveness of API 5L Grade B pipe corrosion inhibitors

Table 6. Effectiveness of chromate inhibitor

\begin{tabular}{cccc}
\hline No & Media & Chromate $(\%)$ & Effectiveness $(\%)$ \\
\hline 1 & Injection Water & 0,1 & 8,40 \\
2 & Injection Water & 0,3 & 13,89 \\
3 & Injection Water & 0,5 & 19,01 \\
4 & Injection Water & 0,7 & 22,39 \\
5 & Injection Water & 0,9 & 34,23 \\
6 & $3,5 \% \mathrm{NaCl}$ solution & 0,1 & 15,59 \\
7 & $3,5 \% \mathrm{NaCl}$ solution & 0,3 & 22,41 \\
8 & $3,5 \% \mathrm{NaCl}$ solution & 0,5 & 24,58 \\
9 & $3,5 \% \mathrm{NaCl}$ solution & 0,7 & 24,63 \\
10 & $3,5 \% \mathrm{NaCl}$ solution & 0,9 & 35,13 \\
\hline
\end{tabular}




\section{CONCLUSION}

The addition of chromate inhibitors to the injection water medium and $3.5 \% \mathrm{NaCl}$ can reduce the corrosion rate of API 5L Grade B pipes. The higher the concentration of the inhibitor, the higher the effectiveness of the inhibitor. In the injection water medium, the corrosion rate dropped from 0.3307 mpy to 0.2175 mpy after adding $0.9 \%$ chromate. In $3.5 \%$ media, the corrosion rate dropped from 0.4960 mpy to 0.3218 mpy after adding $0.9 \%$ chromate.

\section{DAFTAR PUSTAKA}

Annual book of ASTM Standards, ASTM G59-97 Standard Test Method for Conducting Potentiodynamic Polarization Resistance Measurement, ASTM International, 2014.

Annual book of ASTM Standards, ASTM G102 Standard Practice for Calculation of Corrosion Rates and Related Information from Electrochemical Measurement, ASTM International, 2015.

API Specification 5L, Specification for Line Pipe, 2012.

ASM Handbook, Laboratory testing, Volume 13, 1992, ASM International.

ASM Handbook, Aqueous Corrosion Reaction Mechanism, Volume 13A, 2003, ASM International.

ASM Handbook, Methods for Determining Aqueous Corrosion Reaction Rates, Volume 13A, 2003, ASM International.

ASM Handbook, Passivity, Volume 13A, 2003, ASM International.

Diaz, M.D, Aguilar, M.A.D., Tobon, A.C., and Dominguez, B.C., Corrosion Inhibition of pipeline steel X-70 in Sour Brine by an Imidazoline Derivative underflow assisted corrosion, International journal of electrochemical science, 12, 2017, 7481-7501.

Faraq, A. and El-din, M.R.N., The adsorption and corrosion inhibition of some nonionic surcfactants on API X65 steel surface in hydrochloric acid, Corrosion Science, 64, 2012, 174-183.

Finšgar, M., and Jackson, J., Application of corrosion inhibitors for steels in acidic media for the oil and gas industry: A review, Corrosion Science, 86, 2014, 17-41.

Gonzalez, J.A., Vazquez, A.E., Romo, M.R., Chavarin, J.U., and Pardave, M.P., Electrochemical evaluation of cephalotin as corrosion inhibitor for API 5L X52 steel immersed in an acidic medium, Arabian journal of Chemistry, 2015.

Joseph, O.O., Sivaprasad, S., and Fayomi, O.S.I., Comparative study on the effect of NaNO2 in corrosion inhibition of micro-alloyed and API 5L X65 steels in E20 simulated FGE, Energy Procedia, 119, 2017, 953-960.

Meresht, E.S., Farahani, T.S., and Neshati, J., 2-Butyne-1, 4 diol as a novel corrosion inhibitor for API X65 steel pipeline in carbonate/bicarbonate solution, Corrosion Science, 54, 2012, 36-44

Oliviera, L.A., Effect of silicate-based film on the corrosion behavior of the API 5L X80 pipeline steel, Corrosion Science, 139, 2018, 21-34.

Oliveira, M.C., Figueredo, R.M., and Acciari, H.A., Corrosion behavior of API 5L X65 steel subject to plastic deformation, Journal of materials research and technology, 2018. 